EJMBE

30,2

152

Received 26 December 2019 Revised 6 May 2020 10 July 2020

31 July 2020

Accepted 20 August 2020

\section{The risk management role of nonexecutive directors: from capital expenditure perspective}

\author{
Tho Anh To
}

University of Finance and Marketing, Ho Chi Minh City, Vietnam

Yoshihisa Suzuki

Department of Economics, Graduate School of Social Sciences, Hiroshima University, Higashihiroshima, Japan, and

Hong Thu Thi Ho, Siem Thi Tran and Tuan Quoc Tran University of Finance and Marketing, Ho Chi Minh City, Vietnam

\begin{abstract}
Purpose - This study investigates the impact of board independence on firm risk of Vietnamese listed firms and the moderating effect of capital expenditure on this relationship.

Design/methodology/approach - This paper applies fixed effects and dynamic generalized method of moments (GMM) models to examine hypothesized associations between the proportion of nonexecutive directors and stock return volatility, as well as the moderating effect of capital expenditure. The robustness tests are implemented by applying alternative measures of overinvestment and firm risk.

Findings - The results show that the presence of nonexecutive directors on board increases firm risk. However, the combination of nonexecutive ratio and capital expenditure ratio has a significant negative impact on firm risk. The result is also confirmed by the difference between the monitoring role of nonexecutive directors in overinvesting and underinvesting firms.

Research limitations/implications - The results imply that Vietnamese listed firms take stock return volatility into consideration before nominating and appointing nonexecutive directors into their board, especially in overinvesting firms. From another perspective, the shift toward having a majority of nonexecutive directors on boards can play a significant role in pursuing a stable or risky business strategy.

Originality/value - This paper investigates the influences of nonexecutive directors on firm risk in the context of Vietnam.
\end{abstract}

Keywords Vietnam, Nonexecutive director, Overinvestment, Firm risk

Paper type Research paper

\section{Introduction}

Unlike developed economies, developing countries, especially Southeast Asian countries, have had ineffective corporate governance practices. The weaknesses in corporate governance mechanisms had an important effect on the stock market declines in the Asian crisis (Al Farooque et al., 2019; Ghalib, 2018). The establishment of a good corporate governance code has become a significant concern for many Asian governments to prevent

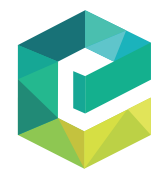

(C) Tho Anh To, Yoshihisa Suzuki, Hong Thu Thi Ho, Siem Thi Tran and Tuan Quoc Tran. Published in European Journal of Management and Business Economics. Published by Emerald Publishing Limited. This article is published under the Creative Commons Attribution (CC BY 4.0) licence. Anyone may reproduce, distribute, translate and create derivative works of this article (for both commercial and noncommercial purposes), subject to full attribution to the original publication and authors. The full terms of this licence may be seen at http://creativecommons.org/licences/by/4.0/legalcode

This study is a part of a Ph.D. dissertation at Hiroshima University, Japan. The corresponding author is the Ph.D. candidate. We would like to thank the editor and two anonymous referees for their useful suggestions and helpful comments on earlier versions of the manuscript. Any remaining errors are our own. 
financial crises, which usually result from a lack of transparency and disclosure in many companies (Connelly et al., 2017). Nonetheless, the studies from developed countries may not be applicable in developing countries because many different factors often fall beneath contextualization, such as the structures of corporate ownership, the strength of institutions, legal and government intervention and so on. (Waweru, 2020).

Notably, the unclear separation of control and management, one of the most noticeable characteristics in Southeast Asian firms' corporate governance systems, has become a major obstacle to monitoring and thus led to potential risks. Therefore, the Vietnamese government issued the Circular 121/2012/TT-BTC dated July 26, providing further regulations on corporate governance applicable to public companies. This is the first official legal document to define the concept of nonexecutive directors in Vietnam, which has an effect of significantly increasing board independence. Although the increase in nonexecutive director ratio is appreciated as a big step in reforming the board structure toward enhancing transparency, the monitoring role of nonexecutive directors in Vietnamese listed companies may still not be effective since nonexecutive directors in emerging markets are often appointed for reasons other than monitoring (Haniffa and Cooke, 2002). Majority shareholders often interfere with the appointment of nonexecutive directors to strengthen their control of the company. Consequently, nonexecutive directors can hardly influence important decisions and gradually play the role of advisors other than supervisors.

Besides, corporate risk in some industries may also come from poor control of investment spending, in which capital expenditure is likely to be one of the important factors (Amir et al., 2007). One of the reasons for the excessive capital expenditures in Vietnamese listed firms may be due to the agency problems between majority and minority shareholders. As supported in many previous studies, the potential agency conflicts in Asian markets are more likely to be large shareholders versus small shareholders, rather than shareholders versus management. Majority shareholders have an incentive to use their control rights to divert funds and resources to other companies or projects they control. In addition to the improved regulation on the separation between ownership and management, the appointment of qualified nonexecutive directors has attracted the interests of noncontrolling shareholders to partially prevent the selfbehavior of entrenched majority shareholders. However, the direct impact of capital expenditure on firm risk (Kothari et al., 2002; Amir et al., 2007) has attracted less attention from researchers than the relationship between capital expenditures and performance (Lev and Thiagrajan, 1993; Chen, 2006; Antia et al., 2010; Mak and Kusnadi, 2005; Chen et al., 2007b), especially for emerging markets. Moreover, the moderating effect of capital expenditure on the above relationship has been a new and unexplored issue, which motivates this paper. It yields an additional insight on the impact of nonexecutive directors on firm risk in the context of Vietnam, a transitional economy characterized by a weak corporate governance system.

This paper is conducted with a sample of 151 listed companies on Vietnamese stock markets from 2007 to 2016, for the purpose of investigating the impact of nonexecutive director ratio on firm risk in the presence of overinvestment. Overall, we find that there is a positive relationship between nonexecutive ratio and firm risk, indicating that the increase in nonexecutive directors makes stock returns more volatile. This result supports the hypothesis that the information and council of executive directors on boards are more important to perform efficiently (De Andres and Vallelado, 2008). However, the risk management role of nonexecutive directors is not completely denied because the incorporation of nonexecutive directors and capital expenditures has a negative impact on firm risk. It implies that companies should maintain boards with a high proportion of nonexecutive directors to reduce risks in the presence of overinvestment.

The remainder of this paper is organized as follows. Section 2 provides the literature and develops hypotheses. The research design is explained in Section 3. Section 4 presents the results of the empirical analysis. The conclusions are summarized in the last section.

\section{Role of nonexecutive directors}


EJMBE 30,2

\section{Literature review and development of hypotheses}

\subsection{The role of nonexecutive directors}

The role of nonexecutive directors in corporate risk management has been supported by many theories. Under the agency theory, more nonexecutive directors on board are generally expected to be effective in providing oversight of firm performance and limiting managerial opportunism (DeBoskey et al.,2018; Persons, 2006). Nonexecutive directors may protect shareholders' interests by affecting important board outcomes and enhancing comprehensive financial disclosures (Kamardin et al., 2017; Lefort and Urzúa, 2008). In addition to the supervising function, a board of directors also plays a role as a primary linkage mechanism that helps a firm to access essential resources, link with its external environment and overcome adverse environmental conditions (Lu and Herremans, 2019; Lai et al., 2019). Therefore, from the perspective of resource dependence theory, nonexecutive directors may provide strategic directions and influence managerial decisions - thanks to their expertise, prestige and contacts (Salem et al., 2019). Furthermore, nonexecutive directors usually serve as external monitoring and advising specialists in the directorship market, and consequently they need to protect their reputation under reputation theory (Bugeja et al., 2016; Masulis and Mobbs, 2014). This is the reason why nonexecutive directors tend to support less risky projects or pursue the risk-reducing strategies of corporate diversification (Pathan, 2009).

On the contrary, many previous studies suggest that the increasing presence of nonexecutive directors is unlikely to bring proper supervision (Raheja, 2005; Kim et al., 2014). According to Adams and Ferreira (2007), too much monitoring could have a negative influence on shareholder value because too intense supervision may also result in managers' more risk-aversion and underinvestment behavior (Hoskisson et al., 2009). Secondly, executive directors may be better monitors because of being better informed about the firm's constraints and opportunities than outside directors (Harris and Raviv, 2008). Thanks to their firm-specific information, they easily deal with problems arising from information asymmetry between the directors and managers (Raheja, 2005). According to Kim et al. (2014), it is costly to transfer firm-specific information to outsiders when these firms have higher information asymmetry. Yammeesri and Kanthi Herath (2010) and Shakir (2008) found that Thai and Malaysian firms with more executive directors performed better. Therefore, there is a little doubt about the monitoring role of nonexecutive directors, especially for firms in developing countries, because nonexecutive directors are often nominated or appointed by majority shareholders who take control of the company.

In Vietnam, although the Vietnam Enterprise Law, which was enacted in 2005, mentioned executive directors, nonexecutive directors and independent directors, the differentiation among them was not clarified (Minh and Walker, 2008). Two years later, they were ambiguously categorized into (1) executive directors and (2) nonexecutive and independent directors in Decision 15/2007/QD-BTC of the Finance Minister on the Model Charter of listed companies and Decision 12/2007/QD-BTC of the Finance Minister on Code of Corporate Governance for Listed Companies on Stock Exchange/Securities Trading Centers, but there was no specific definition of the term "non-executive and independent directors." Until 2012, the Circular 121/2012/TT-BTC on July 26, providing further regulations on corporate governance applicable to public companies, has been considered to be the first official legal document to define nonexecutive directors as members of the board of directors and not by the general manager, deputy general manager, chief accountant or any other managers designated by the board of directors. As an effort to improve and guide the governance of public companies, the government issued Decree 71/2017/ND-CP on June 6th, 2017 and Circular 95/2017/TT-BTC on September 22nd, 2017, which replaced the Circular 121/2012/ TT-BTC. However, the definition of "non-executive directors" under article 2.6 of Decree 71/ 2017/ND-CP and the requirement of at least one-third nonexecutive directors under article 
13.2 of Decree 71/2017/ND-CP remained the same for listed public companies. Notably, the roles of the chairman and chief executive officer (CEO) in a public company must be separated under the article 12.2 of Decree 71, but the prohibition against one person simultaneously holding these two positions shall only be effective as from August 1st, 2020. The delays in issuing relevant regulations make the supervisory role of nonexecutive directors not highly appreciated in risk management.

Besides, many state-owned companies have remained dominant in the Vietnam stock market, and thus nonexecutive positions are sometimes nominated or appointed by state shareholders who take control of the business (Robinett et al., 2013). Communist Party Congress in 2016 has still emphasized the importance of state ownership in serving and maintaining the government's political and social goals, so controlling state shareholders could stand behind politically connected directors or managers (Hu et al., 2010; Nguyen et al., 2017). Therefore, nonexecutive directors usually do not have many incentives to monitor.

Under the resource dependence, the advising and supporting role of nonexecutive directors in Vietnamese companies is not much efficient. First, their appointments are usually driven by friend or family relationships with majority shareholders rather than by expertise and experience. Second, nonexecutive directors typically do not engage in the day-to-day management of the organization and play the role of representatives for large shareholders or portfolio managers, so they may not understand the nature of the business. Hence, this study expects that the presence of more nonexecutive directors can lead to higher firm risk.

H1. The proportion of nonexecutive directors has a positive impact on firm risk.

\subsection{Capital expenditures and firm risk}

According to previous studies, there is a positive association between capital expenditure and financial performance (Lev and Thiagrajan, 1993; Chen, 2006; Antia et al., 2010; Mak and Kusnadi, 2005; Chen et al., 2007b). Lev and Thiagrajan (1993) state that capital expenditure is a significant signal required by the analysts in forecasting future profitability and stock returns. Therefore, investment in capital expenditures is expected to increase market valuation (Antia et al., 2010). Mak and Kusnadi (2005) also find that firms with higher capital expenditures have higher accounting performance. Chen (2006) shows a significantly positive average price response to announcements of corporate capital investments. Chen et al. (2007b) find that the announcement of an increase in capital investments has a positive impact on the stock prices of announcing firms and a negative impact on the stock prices of rival firms.

In major studies on the impact of investment on corporate risk, capital expenditure is only mentioned as an object of comparison with research and development (R\&D) spending. Although capital expenditures are considered as lower risk investments (Kothari et al., 2002), the positive impact of capital expenditures on earnings variability is still confirmed for a sample of roughly 50,000 US firm-year observations from 1972 to 1997 by Kothari et al. (2002). Meanwhile, earnings variability has historically been found to be closely associated with market-based measures of firm risk (Dhaliwal et al., 2017). Additionally, Khan and Bradbury $(2014,2015)$ show that net income volatility has exhibit a strong positive correlation with the volatility of stock returns. Amir et al. (2007) also use both operating income variability and monthly stock return variability as the dependent variables to prove that investments in capital expenditures are likely to be key and hence more closely linked to business risk for many industries.

In Vietnam, state ownership has still accounted for a significant proportion in the listed companies since the shift from a centrally planned economy toward a socialist-oriented market economy in 1986. The government has used state-owned enterprises (SOEs) to pursue socioeconomic and political goals rather than profit maximization (Tu and Nguyen, 2019; 
EJMBE 30,2

Nguyen et al., 2017). In other words, SOEs have been considered as a key component for the intervention and orientation of the government into the market, therefore they must undertake many investments with negative net present values (NPVs), leading to overinvestment problems. Chen et al. (2017a) also state that SOEs' investments are less efficient than nonSOEs'. In fact, Nguyen et al. (2017) also find that Vietnamese listed firms with higher state ownership have lower firm performance. The weak financial performance and inefficient investments of the SOEs is also caused by many different factors such as unclear objectives, poor management, budget constraints (Yang et al., 2015) and lack of transparency or corruption in SOEs' operations (Hai and O'Donnell, 2017). Therefore, the positive association between capital expenditures and firm risk is expected in this paper.

H2. A high level of capital expenditures has a positive impact on firm risk.

\subsection{The interaction of nonexecutive director ratio and capital expenditures}

As mentioned in many research papers related to corporate governance in developed markets, lack of monitoring can increase opportunities for executives to pursue overinvestment strategies to enhance their positions or to maximize their own utility at the expense of shareholders (Titman et al., 2004; Pellicani and Kalatzis, 2019). It is because overconfident executives usually overestimate returns to investment projects, and thus overinvest when they have abundant cash holdings (Malmendier and Tate, 2005). Regarding internal control's role in standardizing corporate investment behavior, strong internal control mechanisms should reduce the likelihood THAT overinvestment becomes a severe problem (Mao et al., 2019). Notably, the presence of outside directors on boards might help mitigate managerial optimism problems and hence reduce the investment distortions inherent to managerial overconfidence (Heaton, 2002; Lai and Liu, 2018). By using the interaction between the proportion of nonexecutive directors and investment, Chung et al. (2003) also find a significant and positive correlation between firm value and investment, as measured by both capital and R\&D expenditures, for firms with a high proportion of outside directors.

However, overinvestment caused by shareholder-manager conflicts in Vietnam and other emerging markets can be addressed by ownership concentration (Taghavi et al., 2014). It is considered a benefit of ownership concentration, especially in countries with weak legal protection (Kong et al., 2020). However, high levels of concentration between ownership and control might also lead to suboptimal investment or overinvestment (De Andres and Vallelado, 2008). Because concentrated ownership can cause conflicts between majority and minority shareholders, and in that case, majority shareholders will use their control rights to maximize their own interest at the expense of other shareholders (Lozano et al., 2016; Pellicani and Kalatzis, 2019). In other words, they have an incentive to payout a larger proportion of company cash flows to themselves instead of evenly distributing funds among all shareholders. One possibility to do so could be to redirect funds to other companies they control.

For companies that expand their scale of investments or invest excessively, they often face a shortage of capital. This problem is indispensable under the increasing pressure of international integration and competition, but it is also an opportunity for the increasing presence of outside investors into the companies' ownership structure (Choi et al., 2014; Wenwei, 2017; Vo and Ellis, 2018). The Vietnam stock market has also witnessed a significant increase in foreign ownership since Vietnam officially became a member of the World Trade Organization in 2007 (Batten and Vo, 2015). Before that, the Vietnamese government decided to transition from a centrally planned economy into a socialist-oriented market economy in 1986. Consequently, listed companies gradually attract external capitals, but majority shareholders still try to retain control of the company; consequently, the outside owners can only nominate or appoint nonexecutive directors, other than executive ones, into the board of 
directors. Despite that, the increasing presence of such nonexecutive directors is expected to change and enhance governance mechanisms in those firms - thanks to their skills and knowledge.

In addition, minority shareholders gradually acknowledge the importance of nonexecutive directors in monitoring and evaluating board's transparency and reliability (Chang et al., 2006) because the selection of qualified nonexecutive directors is also relevant for the protection of minority shareholders with respect to the agency costs of majority shareholders (Wright et al., 2013). In fact, a higher proportion of nonexecutive directors on board could be seen as a significant restructuring of top management under the Circular 121/ 2012/TT-BTC applicable to listed companies in Vietnamese stock markets (Nguyen and Phan, 2016). Therefore, in the case of overinvestment, the increase in the nonexecutive director ratio may help to bring confidence to investors, lenders and minority shareholders.

H3. More nonexecutive directors are needed to control firm risk in the presence of overinvestment

\section{Research design}

\subsection{Sample}

Our research sample comprises of 151 nonfinancial companies listed on Vietnamese stock markets (including HNX - Hanoi Stock Exchange and HOSE - Ho Chi Minh Stock Exchange) from 2007 to 2016. According to the Industry Classification Benchmark (ICB) 2008 applied in Vietnam, the list of publicly listed companies on the two markets (HOSE and HNX) is classified into ten industry sectors: (1) oil and gas, (2) basic materials, (3) industrials, (4) consumer goods, (5) healthcare, (6) consumer services, (7) telecommunications, (8) utilities, (9) financials (including banks, securities companies, insurance companies, real estate and financial services companies) and (10) technology. Financial companies such as banks, securities, insurance and financial services are excluded from the sample because they act as market makers, and more specifically the board structure of these companies must comply with some regulations from the state bank. The year 2007 is chosen as the starting year because Vietnamese Securities Law, which prescribes additional rules for listing stocks, transparency and the disclosure of information by public companies, was issued in June 2006 and took effect on January 1st, 2007. Meanwhile, the paper also collects data about sales growth to measure managerial overinvestment; therefore, financial reports in 2006 are very necessary. The total numbers of listed financial and nonfinancial companies on two securities trading center HNX and HOSE in 2006 are 87 and 106, respectively. Hence, the selected sample is highly representative.

Data for this paper are collected by reviewing annual reports which are available at http:// ezsearch.fpts.com.vn/. The industry classification is provided on www.stockbiz.vn. They are leading websites providing financial information, market data and investing tools for institutional and individual investors in Vietnam (see Table 1).

\subsection{Empirical model}

We test the impact of nonexecutive director ratio on firm risk as well as the moderating role of capital expenditure using the following regression model:

$$
\begin{aligned}
\text { RISK }_{i t}= & \beta_{0}+\beta_{1} \mathrm{NON}_{-} \mathrm{EX}_{i t}+\beta_{2} \mathrm{FSIZE}_{i t}+\beta_{3} \mathrm{~PB}_{i t}+\beta_{4} \mathrm{STDEBT}_{i t}+\beta_{5} \mathrm{CAPEX}_{i t} \\
& +\beta_{6} \mathrm{CASH}_{i t}+\beta_{7} \mathrm{DIV}_{i t}+\beta_{8} \mathrm{NON}_{-} \mathrm{EX}_{i t} * \mathrm{CAPEX}_{i t}+\varepsilon_{i t}
\end{aligned}
$$




\begin{tabular}{llrr} 
EJMBE & Industry & Number of firms & Percent \\
\cline { 2 - 4 } 30,2 & Basic materials & 12 & 7.95 \\
& Consumer goods & 38 & 25.17 \\
& Consumer services & 12 & 7.95 \\
& Health care & 6 & 3.97 \\
& Industrials & 54 & 35.76 \\
$\mathbf{1 5 8}$ & Oil and Gas & 1 & 0.66 \\
\hline Table 1. & Real estate & 14 & 9.27 \\
Sample description by & Utilities & 6 & 3.97 \\
industry & Total & 8 & 5.30 \\
& & 151 & 100.00 \\
\hline
\end{tabular}

Following the studies by Cheng (2008), Nakano and Nguyen (2012) and Wang (2012), we use daily stock returns as a basis for calculating the annual firm risk. RISK1 (total risk) equals the annualized standard deviation of daily stock returns. RISK2 (unsystematic risk) equals the standard deviation of the residuals estimated from the model: $R_{i, t}=\alpha_{i}+\beta_{i} \mathrm{RM}_{t}+\varepsilon_{i, t}$ (where, $R_{i, t}$ donates the daily stock returns; $\mathrm{RM}_{t}$ represents the daily market returns based on the $\mathrm{VN}$ index; and $\varepsilon_{i, t}$ stands for the residuals).

While Florackis and Ozkan (2009) and De Andres and Vallelado (2008) calculate nonexecutive director ratio (NON_EX) as the number of nonexecutive directors divided by the total members in a one-tier board, this paper measures this variable by dividing the number of nonexecutive directors by total members in the board of directors because the board structure of companies listed on Vietnamese stock markets is separated into two tiers: a board of directors and an executive board (Nguyen et al., 2015). By applying this measure, this paper may evaluate the impact of the nonexecutive director ratio on firm risk more properly after controlling for the change of executive board members. In addition, nonexecutive directors are required to retain their seats for more than six months in a fiscal year to ensure that their involvement can have an impact on the performance.

Capital expenditure (CAPEX) is the change in fixed assets plus depreciation scaled by total assets at the beginning of the fiscal year. Huang and Wang (2015) use this ratio as a control variable to investigate the effect of board size on the variability of firm performance, while Mak and Kusnadi (2005) consider it as a determinant of firm performance.

Our regression models incorporate some control variables that previous studies suggest might affect firm risk. Firm size (FSIZE) is calculated as the natural logarithm of total assets. It is selected as a control variable because large firms have more advantages in attracting additional resources, and therefore "larger businesses tend to have larger pools of financial and managerial resources that help overcome problems that threaten their survival' (Mitchell, 1994). Malkiel and $\mathrm{Xu}$ (1997) also find a negative relation between unsystematic risk and firm size. Price to book value $(P B)$ is the ratio of the market value of equity to the book value of equity. Fama and French (1992) suggest that PB may reflect the firm risk. Debt maturity (STDEBT), measured as a short-term debt divided by total debt, plays a significant role in reducing agency costs by increasing frequency of monitoring from lenders to managerial actions and thus enhance information transparency (Datta et al., 2005). Based on the agency arguments, firms with more short-term debt are expected to be associated with a lower risk. Cash ratio $(\mathrm{CASH})$ is calculated as the ratio of cash and equivalent cash to total assets. Mikkelson and Partch (2003) and Almeida et al. (2004) consider cash holdings as an effective risk management tool. Dividend payment (DIV) is the ratio of dividend payout to total assets (Jiraporn et al., 2011). Pástor and Pietro (2003) and Bartram et al. (2015) indicate the negative association between dividend payment and corporate risk. Paying more dividends to reduce 
the cash in hand is usually considered as a mechanism to avoid overinvestment and consequently mitigate agency problems between managers and shareholders (Farre-Mensa et al., 2014).

\section{Results and discussion}

Descriptive statistics of the research variables are presented in Table 2. The average total risk (unsystematic risk) of companies listed on Vietnamese stock markets is 3.1\% (2.9\%). The average proportion of nonexecutive directors is around $63.1 \%$. It means that on average, there are from three to seven nonexecutive directors serving on a supervisory board because the total number of members on this board for listed companies must comprise $5-11$ members (under article 30 of Circular 121/2012/TT-BTC). The mean capital expenditure ratio is 7\%, which is not much different from the reported figure $(4.8 \%)$ in the research by Huang and Wang (2015) for Chinese firms over the period 2003-2011.

Table 3 presents the correlation matrix among the variables. The correlations between nonexecutive director ratio and total risk/unsystematic risk are -0.057 and -0.033 , respectively. They demonstrate the role of nonexecutive directors in controlling firm risk. Meanwhile, the correlation with capital expenditure ratio is positive, which indicates that capital expenditures cause the volatility of stock returns. Because all the correlation coefficients are lower than 0.8 , the model is not at risk of violating multicollinearity (Gujarati and Porter, 2003).

Table 4 shows the results of the fixed effects estimations. After controlling for serial correlation and heteroskedasticity by using clustered standard errors, firm risk is generally higher when companies have more capital expenditures, as the coefficients on capital expenditure fetch a positive sign and are statistically significant (except for the result in column 3). This finding is consistent with Kothari et al. (2002) and Amir et al. (2007) that show the positive impact of capital expenditure on corporate risk. Table 4 also displays the positive coefficients on nonexecutive director ratio, indicating that firm risk will increase as the proportion of nonexecutive directors increases. They are statistically significant at $1 \%$ level under both risk measures, providing strong evidence to support the arguments of Adams and Ferreira (2007) and Raheja (2005) that companies face high monitoring costs when they increase the number of nonexecutive directors on board. It is because nonexecutive directors

\begin{tabular}{lrrrrrrrr}
\hline & & & Std. & $\begin{array}{c}\text { 5th } \\
\text { percentile }\end{array}$ & $\begin{array}{c}\text { 25th } \\
\text { percentile }\end{array}$ & $\begin{array}{c}\text { 50th } \\
\text { percentile }\end{array}$ & $\begin{array}{c}\text { 75th } \\
\text { percentile }\end{array}$ & $\begin{array}{c}\text { 95th } \\
\text { percentile }\end{array}$ \\
\hline RISK1 & 1,405 & 0.031 & 0.009 & 0.018 & 0.025 & 0.030 & 0.036 & 0.047 \\
RISK2 & 1,405 & 0.029 & 0.009 & 0.017 & 0.023 & 0.028 & 0.034 & 0.046 \\
NON_EX & 1,510 & 0.631 & 0.178 & 0.333 & 0.571 & 0.600 & 0.800 & 0.857 \\
FSIZE & 1,510 & 13.215 & 1.340 & 11.111 & 12.292 & 13.153 & 14.006 & 15.651 \\
PB & 1,370 & 1.294 & 1.251 & 0.280 & 0.590 & 0.940 & 1.540 & 3.380 \\
STDEBT & 1,510 & 0.829 & 0.222 & 0.313 & 0.730 & 0.935 & 0.992 & 1.000 \\
CAPEX & 1,510 & 0.070 & 0.174 & -0.055 & 0.005 & 0.030 & 0.093 & 0.304 \\
CASH & 1,510 & 0.105 & 0.113 & 0.007 & 0.029 & 0.066 & 0.147 & 0.332 \\
DIV & 1,510 & 0.033 & 0.044 & 0.000 & 0.001 & 0.021 & 0.044 & 0.116
\end{tabular}

Note(s): The table presents descriptive statistics among the variables of this study, where RISK1 is total risk, RISK2 is unsystematic risk, NON_EX is the percentage of nonexecutive on the supervisory board, FSIZE is natural logarithm of total assets, $\mathrm{PB}$ is the market value to book value of equity, STDEBT is the ratio of shortterm debt to total debt, CAPEX is the change in fixed assets plus depreciation scaled by total assets at the beginning of the fiscal year, CASH is calculated as cash and equivalent cash divided by total assets and DIV is the ratio of dividend payout to total assets

\section{Role of nonexecutive directors}


EJMBE 30,2

\section{0}

Table 3.

Correlation matrix

do not engage in the day-to-day management of the organization. In addition, the appointment of nonexecutive directors in Vietnamese listed companies is usually interfered by majority shareholders who take control of the company, so the monitoring activities from nonexecutive directors to resolve disputes between owners and managers become less important. This result is contrary to that of Mathew et al. (2016), who suggest that nonexecutive directors' impact on firm risk is negative, for a sample of 260 UK companies in the 2005-2010 period. Sá et al. (2017) also find a negative and statistically significant relationship between changes in both total and idiosyncratic risk and the ratio of nonexecutive directors, for companies listed in the Euronext Lisbon (Portuguese Stock Exchange). The difference implies that the monitoring role of nonexecutive directors in Vietnamese firms is not appreciated as highly as in developed countries, where shareholdermanager agency conflict is typical.

However, the risk management role of nonexecutive directors is not completely denied because the estimated coefficients on the interaction terms between nonexecutive director ratio and capital expenditure ratio turn out to be significantly negative at $5 \%$ level and $10 \%$ level. They demonstrate the moderating role of capital expenditures in the relationship between nonexecutive directors and firm risk. More remarkably, the absolute values of these

\begin{tabular}{lrrrrrrrr}
\hline & RISK1 & RISK2 & NON_EX & FSIZE & PB & STDEBT & CAPEX & CASH \\
\hline NON_EX & -0.057 & -0.033 & & & & & & \\
FSIZE & -0.379 & -0.449 & 0.122 & & & & & \\
PB & 0.041 & 0.028 & 0.010 & 0.054 & & & & \\
STDEBT & -0.006 & 0.053 & -0.012 & -0.326 & 0.032 & & & \\
CAPEX & 0.121 & 0.045 & -0.028 & 0.036 & 0.117 & -0.163 & & \\
CASH & -0.092 & -0.078 & 0.066 & -0.012 & 0.159 & 0.167 & -0.012 & \multirow{2}{*}{0.362} \\
DIV & -0.199 & -0.202 & 0.058 & -0.084 & 0.282 & 0.176 & -0.003 & \\
Note(s): Variables are defined the same as in Table 2 & & & & \\
\hline
\end{tabular}

\begin{tabular}{lcccc}
\hline \multicolumn{2}{c}{ RISK1 } & \multicolumn{2}{c}{ RISK2 } \\
\hline NON_EX & $0.00621^{* * *}(2.82)$ & $0.00702^{* * * *(3.08)}$ & $0.00535^{* * *}(2.64)$ & $0.00598^{* * *}(2.86)$ \\
FSIZE & $-0.00274^{* * *}(-3.49)$ & $-0.00269^{* * *}(-3.46)$ & $-0.00339^{* * *}(-4.27)$ & $-0.00335^{* * *}(-4.26)$ \\
PB & $0.000396(1.09)$ & $0.000390(1.09)$ & $0.000407(1.06)$ & $0.000402(1.06)$ \\
STDEBT & $-0.00171(-1.03)$ & $-0.00130(-0.77)$ & $-0.00150(-0.91)$ & $-0.00118(-0.71)$ \\
CAPEX & $0.00209^{* *}(2.14)$ & $0.00997^{* *}(2.39)$ & $0.00157(1.54)$ & $0.00768^{*}(1.95)$ \\
CASH & $0.00396(1.45)$ & $0.00401(1.47)$ & $0.00462^{*}(1.67)$ & $0.00466^{*}(1.68)$ \\
DIV & $-0.0164^{* *}(-2.53)$ & $-0.0167^{* * *}(-2.62)$ & $-0.0203^{* * *}(-3.17)$ & $-0.0205^{* * *}(-3.24)$ \\
NON_EX*CAPEX & & $-0.0116^{* *}(-2.08)$ & & $-0.00902^{*}(-1.73)$ \\
Constant & $0.0675^{* * *}(6.52)$ & $0.0659^{* * *}(6.35)$ & $0.0740^{* * *}(7.08)$ & $0.0728^{* * * *}(6.93)$ \\
Year fixed & Yes & Yes & Yes & Yes \\
Firm fixed & Yes & Yes & & Yes \\
Model fits & & & 0.1263 & 01278 \\
Within $R 2$ & 0.2366 & 0.2387 & 0.3736 & 0.3698 \\
Between $R 2$ & 0.2538 & 0.2482 & 0.2523 & 0.2511 \\
Overall $R 2$ & 0.2439 & 0.2429 & $7.47^{* * *}$ & $7.46^{* * *}$ \\
$F$-statistics & $17.19 * * *$ & $17.60^{* * *}$ & 0.0158 & 0.0097 \\
Hausman test & 0.0003 & 0.0002 & 1,360 & 1,360 \\
Obs & 1,360 & 1,360 &
\end{tabular}

Table 4.

Fixed effects regression results
Note(s): Variables are defined the same as in Table 2. Robust t-statistics adjusted for firm-level clustering are reported in parentheses. $* * *, * *$ and $*$ denote significance at the $1 \%, 5 \%$ and $10 \%$ levels, respectively 
coefficients are greater than those of nonexecutive director ratio and capital expenditure ratio. All suggest that a higher proportion of nonexecutive directors tends to weaken the volatility of stock returns in case that companies increase investment. In other words, maintaining a high proportion of nonexecutive directors in firms with more capital expenditures are likely to be effective in reducing firm risk. Hausman tests are also reported in Table 4. They indicate that the fixed effects models are preferred to the random effects models.

To investigate the final hypothesis in more detail, we split the original sample into firms with overinvestment and firms with underinvestment. In this paper, two measures of overinvestment are conducted as follows:

Measure 1: According to Biddle et al. (2009) and Gomariz and Ballesta (2014), overinvestment is measured based on the deviation from the regression model:

$$
\mathrm{CAPEX}_{i t}=\beta_{0}+\beta_{1} \mathrm{SALE}_{-} \mathrm{GRT}_{i t-1}+\varepsilon_{i t}
$$

CAPEX $_{i t}$ is the capital expenditure of company $i$ for year $t$, and SALE_GRT $i t-1$ is the growth rate of sales during the last year. We conduct Eqn (2) regression cross-sectionally for each industry-year and define the first variable overinvestment as a dummy variable that takes on the value of 1 if the residual is positive and 0 otherwise.

Measure 2: The second overinvestment is also a dummy, which takes on the value of 1 if capital expenditure ratio in a company is more than the median industry-year adjusted capital expenditure ratio and 0 otherwise. This measure follows the approach developed by Bates (2005), which determines whether firms overinvest by comparing the capital expenditure ratios of each firm operating in a given industry in a given year with the median ratio of all firms operating in the same industry during that year.

The estimates presented in Table 5 and 6 show that increasing board independence in firms with overinvestment help to control firm risk. For underinvesting firms, the nonexecutive director ratio is strongly and positively associated with firm risk at the significance level of $1 \%$ under two risk measures. On the other hand, the coefficients on nonexecutive director ratio are still positive but weakly significant for firms with

\begin{tabular}{|c|c|c|c|c|}
\hline \multirow[b]{2}{*}{ Dependent variable RISK1 } & \multicolumn{2}{|c|}{ Overinvesting firms } & \multicolumn{2}{|c|}{ Underinvesting firms } \\
\hline & (Measure 1) & (Measure 2) & (Measure 1) & (Measure 2) \\
\hline NON_EX & $0.00596 *(1.72)$ & $0.00776 * *(2.39)$ & $0.00837 * * *(2.96)$ & $0.0116 * * *(3.79)$ \\
\hline FSIZE & $-0.00382^{* *}(-2.48)$ & $-0.00372 * * *(-3.15)$ & $-0.00167 *(-1.66)$ & $-0.00118(-0.79)$ \\
\hline $\mathrm{PB}$ & $-0.000491(-1.01)$ & $0.000377(0.80)$ & $0.000113(0.20)$ & $0.000358(0.83)$ \\
\hline STDEBT & $-0.0000638(-0.02)$ & $0.000471(0.17)$ & $0.000111(0.05)$ & $-0.00383(-1.53)$ \\
\hline CAPEX & $0.0195 * * *(2.81)$ & $0.0145 * *(2.19)$ & $-0.00178(-0.19)$ & $-0.00391(-0.46)$ \\
\hline CASH & $0.00883^{* *}(2.20)$ & $0.0101 * *(2.27)$ & $-0.00115(-0.37)$ & $-0.00285(-0.91)$ \\
\hline DIV & $-0.00216(-0.23)$ & $-0.0229 * *(-2.34)$ & $-0.0174 *(-1.75)$ & $-0.0123(-1.31)$ \\
\hline NON_EX*CAPEX & $-0.0228 * *(-2.26)$ & $-0.0188 * *(-2.13)$ & $0.00530(0.38)$ & $0.00330(0.24)$ \\
\hline Constant & $0.0798 * * *(3.89)$ & $0.0775 * * *(5.02)$ & $0.0532 * * *(3.92)$ & $0.0466 * *(2.30)$ \\
\hline Year fixed & Yes & Yes & Yes & Yes \\
\hline Firm fixed & Yes & Yes & Yes & Yes \\
\hline \multicolumn{5}{|l|}{ Model fits } \\
\hline Within $R 2$ & 0.2569 & 0.2766 & 0.1858 & 0.2213 \\
\hline Between $R 2$ & 0.1726 & 0.1965 & 0.2540 & 0.0896 \\
\hline Overall $R 2$ & 0.2203 & 0.2229 & 0.2123 & 0.1704 \\
\hline$F$-statistics & $9.38 * * *$ & $10.52^{* * * *}$ & $9.60 * * *$ & $7.25 * * *$ \\
\hline Obs & 501 & 685 & 764 & 675 \\
\hline
\end{tabular}

Note(s): Variables are defined the same as in Table 2. Robust t-statistics adjusted for firm-level clustering are reported in parentheses. $* * *, * *$ and $*$ denote significance at the $1 \%, 5 \%$ and $10 \%$ levels, respectively

\section{Role of \\ nonexecutive directors}

-

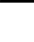


EJMBE

30,2

162

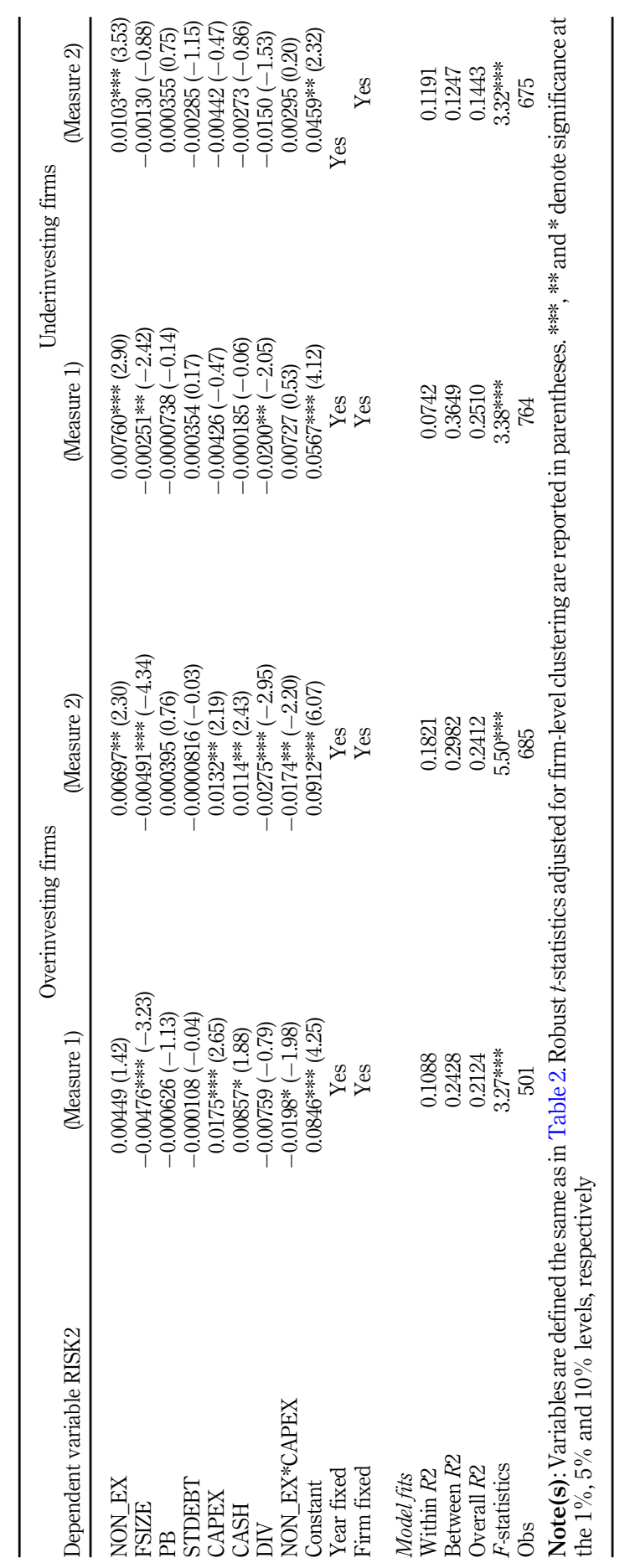

Table 6.

Effect of

overinvestment on the relationship between NON_EX and RISK2 
overinvestment. Moreover, the coefficients on nonexecutive director ratio have smaller absolute values for firms with overinvestment. One possible explanation is that companies seem to pay more attention to the role of nonexecutive directors as they have more capital expenditures. Regarding the interaction term, its coefficients are only negatively significant for overinvesting firms. Furthermore, the absolute values of these coefficients are greater than those of nonexecutive director ratio and capital expenditure ratio. As expected, these results are in line with our third hypothesis. All the above results support that excessive capital spending in some firms poses risks to noncontrolling shareholders who tend to demand increased supervision from nonexecutive directors to minimize losses for themselves. In addition, increasing the presence of nonexecutive directors can also be explained under resource dependence theory that outside directors serve to coordinate organizational action and provide external links to reduce risk (Lu and Herremans, 2019; Lai et al., 2019), especially for firms with many investment activities.

Although the fixed effects method is quite common for panel data, the estimated results may be inconsistent in case of potential endogeneity problems (Shao, 2019; Sewpersadh, 2019; Eugster, 2020). First, simultaneity can exist in the relationship between firm risk and board structure variables (Cheng, 2008; Wang, 2012; Huang and Wang, 2015; Akbar et al., 2017). For instance, nonexecutive director ratio in a period may lead to an increase in stock return volatility in that period while the reverse relationship can also be accepted. Second, nonexecutive director ratio is not completely independent of the lagged firm risk, which is stated as dynamic endogeneity by Wintoki et al. (2012). Both imply that firms with high volatility in the previous or current year can decrease the number of nonexecutive directors in the current year to improve the efficiency of board activities. To prevent the bias in coefficient estimates in Table 4, we reestimate our models by dynamic GMM panel estimation technique proposed by Blundell and Bond (1998) and Roodman (2009). It allows treating all the explanatory variables as endogenous variables (Roodman, 2009; Papangkorn et al., 2019; Liu et al.,2019). Using a list of proper instrumental variables, the application of dynamic GMM helps to solve the endogeneity problems which arise from simultaneity and dynamic endogeneity (Shao, 2019; del Carmen Briano-Turrent and Rodríguez-Ariza, 2016; Akbar et al., 2017; Waheed and Malik, 2019). In many previous studies, dynamic endogeneity is usually ignored because of being difficult to identify exogenous instruments (Wintoki et al., 2012; Sewpersadh, 2019).

By using the same instrument variables for all GMM models on the purpose of comparison, the interpretation of the significant coefficients on nonexecutive director ratio and interaction term in Table 7 remains the same as in Table 4. Regarding the moderating effect of capital expenditure, the coefficients on the interaction term remain negatively significant for all the columns, reinforcing the results in Table 4. Moreover, the robustness of our model estimators is confirmed by the specification tests for system GMM. As expected, the Hansen test indicates that the instruments used in the GMM estimations are not correlated with the error terms. Although there is evidence for negative first-order serial correlation, second-order serial correlation is absent. Wintoki et al. (2012) argue that serial correlation might exist in the first differences AR(1), but there should be no serial correlation in the second differences AR(2). All findings further support the conclusion that the instruments are used reasonably and the above GMM model is consistent.

\section{Conclusion}

After controlling for the problem of heteroskedasticity, autocorrelation and potential endogeneity by applying fixed effects with clustered robust standard errors and dynamic GMM for a sample of 151 companies listed on Vietnamese stock markets in the period 2007-2016, this paper shows the positive impact of nonexecutive director ratio on firm risk. It demonstrates that the inclusion of more nonexecutive directors does not benefit the monitoring function. However, the monitoring 
EJMBE

30,2

\section{4}

Table 7.

Dynamic GMM

regression results

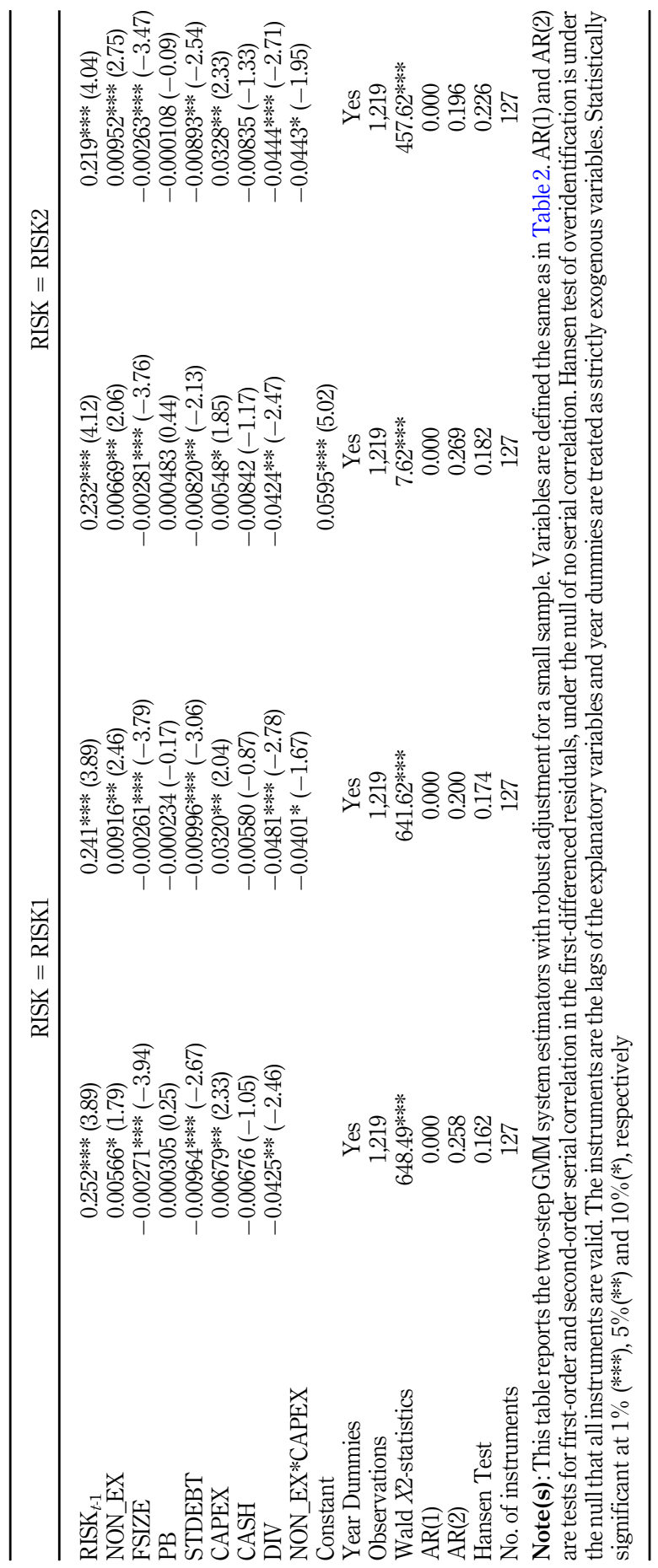

还焉. ․ㅗㅇ

记

ए

of

$\Xi$

记

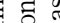

政 웡

政,

更

焉

물

s.

羟

完

苍苞

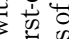

客

. 政

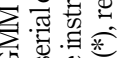
웧ㅎㅇㅇㅇ

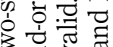
定 음

原

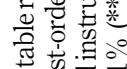
手

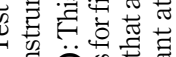

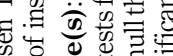

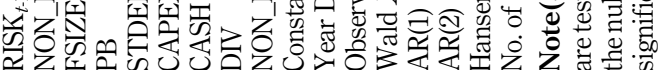


role of nonexecutive directors is improved in the case of overinvestment. This finding is achieved by investigating the moderating role of capital expenditureas well as the difference in theimpact of nonexecutive director ratio on firm risk in case of overinvestment and underinvestment. It suggests that the presence of nonexecutive directors in firms with more capital expenditures is likely to mitigate the volatility of stock returns. In other words, firms with high capital expenditures tend to urgenonexecutivedirectors to increase supervisionas wellas to providemore links to external resources for minimizing risks.

From an application standpoint, the results recommend that the listed firms should consider stock return volatility before they intend to nominate and appoint nonexecutive directors into their board, especially in overinvesting firms. From another perspective, the shift toward having a majority of nonexecutive directors on boards can play a significant role in pursuing a stable or risky business strategy.

By using alternative measures of overinvestment and firm risk, our findings are robust enough to highlight the importance of adjusting an appropriate proportion of nonexecutive directors in managing risks in Vietnam boardrooms, especially from a capital expenditure perspective. It also helps Vietnamese lawmakers understand more corporate governance practices thoroughly and then improve current legislation.

However, this study has several limitations that call for future research. We do not have enough information to differentiate whether a nonexecutive director is nominated and appointed by controlling shareholders or minority shareholders. Separating nonexecutive directors into two groups is important in assessing whether nonexecutive directors are representing the interests of minority shareholders or they are under the control of controlling shareholders. Besides, the paper was also limited to the detailed identification of nonexecutive directors' characteristics. It would, therefore, be interesting to investigate the effects of nonexecutive directors' specific characteristics such as demographics in terms of age, gender and experience; individual and representative ownership; their foreign ownership ratio and so forth to better explain the role of foreign investors in the stability of the Vietnam stock market.

\section{References}

Adams, R.B. and Ferreira, D. (2007), "A theory of friendly boards", The Journal of Finance, Vol. 62 No. 1, pp. 217-250.

Akbar, S., Kharabsheh, B., Poletti-Hughes, J. and Shah, S.Z.A. (2017), "Board structure and corporate risk taking in the UK financial sector", International Review of Financial Analysis, Vol. 50, pp. 101-110.

Al Farooque, O., Buachoom, W. and Hoang, N. (2019), "Interactive effects of executive compensation, firm performance and corporate governance: evidence from an Asian market”, Asia Pacific Journal of Management, Vol. 36 No. 4, pp. 1111-1164.

Almeida, H., Campello, M. and Weisbach, M.S. (2004), "The cash flow sensitivity of cash", Journal of Finance, Vol. 59 No. 4, pp. 1777-1804.

Amir, E., Guan, Y. and Livne, G. (2007), "The association of R\&D and capital expenditures with subsequent earnings variability”, Journal of Business Finance and Accounting, Vol. 34 Nos 1-2, pp. 222-246.

Antia, M., Pantzalis, C. and Park, J.C. (2010), "CEO decision horizon and firm performance: an empirical investigation", Journal of Corporate Finance, Vol. 16 No. 3, pp. 288-301.

Bartram, S.M., Brown, G.W. and Waller, W. (2015), "How important is financial risk?”, Journal of Financial and Quantitative Analysis, Vol. 50 No. 4, pp. 801-824.

Bates, T.W. (2005), "Asset sales, investment opportunities, and the use of proceeds", The Journal of Finance, Vol. 60 No. 1, pp. 105-135. 
EJMBE 30,2

Batten, J.A. and Vo, X.V. (2015), "Foreign ownership in emerging stock markets", Journal of Multinational Financial Management, Vol. 32, pp. 15-24.

Biddle, G.C., Hilary, G. and Verdi, R.S. (2009), "How does financial reporting quality relate to investment efficiency?", Journal of Accounting and Economics, Vol. 48 Nos 2-3, pp. 112-131.

Blundell, R. and Bond, S. (1998), "Initial conditions and moment restrictions in dynamic panel data models", Journal of Econometrics, Vol. 87 No. 1, pp. 115-143.

Bugeja, M., Fohn, S. and Matolcsy, Z. (2016), "Determinants of the levels and changes in non-executive director compensation", Accounting and Finance, Vol. 56 No. 3, pp. 627-667.

Chang, C.Y., Chou, H.Y. and Wang, M.T. (2006), "Characterizing the corporate governance of UK listed construction companies", Construction Management and Economics, Vol. 24 No. 6, pp. 647-656.

Chen, S.S. (2006), "The economic impact of corporate capital expenditures: focused firms versus diversified firms", Journal of Financial and Quantitative Analysis, Vol. 41 No. 2, pp. 341-355.

Chen, R., El Ghoul, S., Guedhami, O. and Wang, H. (2017), "Do state and foreign ownership affect investment efficiency? Evidence from privatizations", Journal of Corporate Finance, Vol. 42, pp. 408-421.

Chen, S.S., Ho, L.C. and Shih, Y.C. (2007), "Intra-lndustry effects of corporate capital investment announcements", Financial Management, Vol. 36 No. 2, pp. 1-21.

Cheng, S. (2008), "Board size and the variability of corporate performance", Journal of Financial Economics, Vol. 87 No. 1, 157176.

Choi, H.M., Cho, Y.G. and Sul, W. (2014), "Ownership-control disparity and foreign investors' ownership: evidence from the Korean stock market", Emerging Markets Finance and Trade, Vol. 50 No. sup1, pp. 178-193.

Chung, K.H., Wright, P. and Kedia, B. (2003), “Corporate governance and market valuation of capital and R\&D investments", Review of Financial Economics, Vol. 12 No. 2, pp. 161-172.

Connelly, J.T., Limpaphayom, P., Nguyen, H.T. and Tran, T.D. (2017), "A tale of two cities: economic development, corporate governance and firm value in Vietnam", Research in International Business and Finance, Vol. 42, pp. 102-123.

del Carmen Briano-Turrent, G. and Rodríguez-Ariza, L. (2016), "Corporate governance ratings on listed companies: an institutional perspective in Latin America", European Journal of Management and Business Economics, Vol. 25 No. 2, pp. 63-75.

Datta, S., Iskandar-Datta, M. and Raman, K. (2005), "Managerial stock ownership and the maturity structure of corporate debt", The Journal of Finance, Vol. 60 No. 5, pp. 2333-2350.

De Andres, P. and Vallelado, E. (2008), "Corporate governance in banking: the role of the board of directors", Journal of Banking and Finance, Vol. 32 No. 12, pp. 2570-2580.

DeBoskey, D.G., Luo, Y. and Wang, J.J. (2018), "Do specialized board committees impact the transparency of corporate political disclosure? Evidence from S\&P 500 companies", Research in Accounting Regulation, Vol. 30 No. 1, pp. 8-19.

Dhaliwal, D.S., Lee, H.S., Pincus, M. and Steele, L.B. (2017), “Taxable income and firm risk”, Journal of American Taxation Association, Vol. 39 No. 1, pp. 1-24.

Eugster, F. (2020), "Endogeneity and the dynamics of voluntary disclosure quality: is there really an effect on the cost of equity capital?", Contemporary Accounting Research, Forthcoming, available at: https://onlinelibrary.wiley.com/doi/epdf/10.1111/1911-3846.12584.

Fama, E.F. and French, K.R. (1992), "The cross-section of expected stock returns", The Journal of Finance, Vol. 47 No. 2, pp. 427-465.

Farre-Mensa, J., Michaely, R. and Schmalz, M. (2014), "Payout policy", Annual Review of Financial Economics, Vol. 6 No. 1, pp. 75-134.

Florackis, C. and Ozkan, A. (2009), "The impact of managerial entrenchment on agency costs: an empirical investigation using UK panel data”, European Financial Management, Vol. 15 No. 3, pp. 497-528.

Ghalib, S. (2018), "Good corporate governance rating and bank profitability in Indonesia: evidence form panel data”, International Journal of Business and Society, Vol. 19 No. 3, pp. 570-586. 
Gomariz, M.F.C. and Ballesta, J.P.S. (2014), "Financial reporting quality, debt maturity and investment efficiency", Journal of Banking and Finance, Vol. 40, pp. 494-506.

Gujarati, D.N. and Porter, D.C. (2003), Basic Econometrics, 4th ed., McGrew Hill Book, Singapore.

Hai, N.M. and O'Donnell, M. (2017), "Reforming state-owned enterprises in Vietnam: the contrasting cases of Vinashin and Viettel", Asian Perspective, Vol. 41 No. 2, pp. 215-237.

Haniffa, R.M. and Cooke, T.E. (2002), "Culture, corporate governance and disclosure in Malaysian corporations", Abacus, Vol. 38 No. 3, pp. 317-349.

Harris, M. and Raviv, A. (2008), "A theory of board control and size”, Review of Financial Studies, Vol. 21 No. 4, pp. 1797-1832.

Heaton, J.B. (2002), "Managerial optimism and corporate finance", Financial Management, Vol. 31 No. 2, pp. 33-45.

Hoskisson, R.E., Castleton, M.W. and Withers, M.C. (2009), "Complementarity in monitoring and bonding: more intense monitoring leads to higher executive compensation", Academy of Management Perspectives, Vol. 23 No. 2, pp. 57-74.

Hu, H.W., Tam, O.K. and Tan, M.G.S. (2010), "Internal governance mechanisms and firm performance in China”, Asia Pacific Journal of Management, Vol. 27 No. 4, pp. 727-749.

Huang, Y.S. and Wang, C.J. (2015), “Corporate governance and risk-taking of Chinese firms: the role of board size", International Review of Economics and Finance, Vol. 37, pp. 96-113.

Jiraporn, P., Kim, J.C. and Kim, Y.S. (2011), "Dividend payouts and corporate governance quality: an empirical investigation”, Financial Review, Vol. 46 No. 2, pp. 251-279.

Kamardin, H., Bakar, R.A. and Ishak, R. (2017), "Intellectual capital disclosure: the effect of family and non-executive directors on board", Advanced Science Letters, Vol. 23 No. 4, pp. 3102-3106.

Khan, S. and Bradbury, M.E. (2014), "Volatility and risk relevance of comprehensive income", Journal of Contemporary Accounting and Economics, Vol. 10, pp. 76-85.

Khan, S. and Bradbury, M.E. (2015), "The volatility of comprehensive income and its association with market risk", Accounting and Finance, Vol. 56 No. 3, pp. 727-748.

Kim, K., Mauldin, E. and Patro, S. (2014), "Outside directors and board advising and monitoring performance", Journal of Accounting and Economics, Vol. 57 No. 2, pp. 110-131.

Kong, Y., Famba, T., Chituku-Dzimiro, G., Sun, H. and Kurauone, O. (2020), "Corporate governance mechanisms, ownership and firm value: evidence from listed Chinese firms", International Journal of Financial Studies, Vol. 8 No. 2, p. 20.

Kothari, S.P., Laguerre, T.E. and Leone, A.J. (2002), "Capitalization versus expensing: evidence on the uncertainty of future earnings from capital expenditures versus R\&D outlays", Review of Accounting Studies, Vol. 7 No. 4, pp. 355-382.

Lai, S.M. and Liu, C.L. (2018), "Management characteristics and corporate investment efficiency", AsiaPacific Journal of Accounting and Economics, Vol. 25 Nos 3-4, pp. 295-312.

Lai, J.H., Chen, L.Y. and Song, S. (2019), "How outside directors' human and social capital create value for corporate international investments", Journal of World Business, Vol. 54 No. 2, pp. 93-106.

Lefort, F. and Urzúa, F. (2008), "Board independence, firm performance and ownership concentration: evidence from Chile", Journal of Business Research, Vol. 61 No. 6, pp. 615-622.

Lev, B. and Thiagarajan, S.R. (1993), "Fundamental information analysis", Journal of Accounting Research, Vol. 31 No. 2, pp. 190-215.

Liu, Y., Brahma, S. and Boateng, A. (2019), "Impact of ownership structure and ownership concentration on credit risk of Chinese commercial banks", International Journal of Managerial Finance, Vol. 16 No. 2, pp. 253-272.

Lozano, M.B., Martínez, B. and Pindado, J. (2016), "Corporate governance, ownership and firm value: drivers of ownership as a good corporate governance mechanism”, International Business Review, Vol. 25 No. 6, pp. 1333-1343. 
EJMBE 30,2

Lu, J. and Herremans, I.M. (2019), "Board gender diversity and environmental performance: an industries perspective", Business Strategy and the Environment, Vol. 28 No. 7, pp. 1449-1464.

Mak, Y.T. and Kusnadi, Y. (2005), "Size really matters: further evidence on the negative relationship between board size and firm value", Pacific-Basin Finance Journal, Vol. 13 No. 3, pp. 301-318.

Malkiel, B.G. and Xu, Y. (1997), "Risk and return revisited", The Journal of Portfolio Management, Vol. 23 No. 3, pp. 9-14.

Malmendier, U. and Tate, G. (2005), "CEO overconfidence and corporate investment”, The Journal of Finance, Vol. 60 No. 6, pp. 2661-2700.

Mao, C., Li, Y. and Liu, M. (2019), "Influence of internal control on inefficient investment of Chinese port listed companies", Journal of Coastal Research, Vol. 98 No. sp1, pp. 34-37.

Masulis, R.W. and Mobbs, S. (2014), "Independent director incentives: where do talented directors spend their limited time and energy?", Journal of Financial Economics, Vol. 111 No. 2, pp. 406-429.

Mathew, S., Ibrahim, S. and Archbold, S. (2016), "Boards attributes that increase firm risk - evidence from the UK", Corporate Governance, Vol. 16 No. 2, pp. 233-258.

Mikkelson, W.H. and Partch, M.M. (2003), "Do persistent large cash reserves hinder performance?", The Journal of Financial and Quantitative Analysis, Vol. 38 No. 2, pp. 275-294.

Minh, T.L. and Walker, G. (2008), "Corporate governance of listed companies in Vietnam”, Bond Law Review, Vol. 20, p. i.

Mitchell, W. (1994), "The dynamics of evolving markets: the effects of business sales and age on dissolutions and divestitures", Administrative Science Quarterly, Vol. 39 No. 4, pp. 575-602.

Nakano, M. and Nguyen, P. (2012), "Board size and corporate risk taking: further evidence from Japan”, Corporate Governance: An International Review, Vol. 20 No. 4, pp. 369-387.

Nguyen, D.T. and Phan, A.T. (2016), "Corporate governance, financial leverage and performance of privatized firms in Vietnam", The 8th Thailand-Japan International Academic Conference 2016.

Nguyen, T., Locke, S. and Reddy, K. (2015), "Does boardroom gender diversity matter? Evidence from a transitional economy", International Review of Economics and Finance, Vol. 37, pp. 184-202.

Nguyen, T.T.M., Evans, E. and Lu, M. (2017), "Independent directors, ownership concentration and firm performance in listed companies: evidence from Vietnam", Pacific Accounting Review, Vol. 29 No. 2, pp. 204-226.

Papangkorn, S., Chatjuthamard, P., Jiraporn, P. and Chueykamhang, S. (2019), "Female directors and firm performance: evidence from the great recession", International Review of Finance, Forthcoming, available at: https://onlinelibrary.wiley.com/doi/epdf/10.1111/1911-3846.12584.

Pástor, L. and Pietro, V. (2003), "Stock valuation and learning about profitability", The Journal of Finance, Vol. 58 No. 5, pp. 1749-1789.

Pathan, S. (2009), "Strong boards, CEO power and bank risk-taking", Journal of Banking and Finance, Vol. 33 No. 7, pp. 1340-1350.

Pellicani, A.D. and Kalatzis, A.E.G. (2019), "Ownership structure, overinvestment and underinvestment: evidence from Brazil”, Research in International Business and Finance, Vol. 48, pp. 475-482.

Persons, O.S. (2006), "Corporate governance and non-financial reporting fraud", The Journal of Business and Economic Studies, Vol. 12 No. 1, p. 27.

Raheja, C.G. (2005), "Determinants of board size and composition: a theory of corporate boards", Journal of Financial and Quantitative Analysis, Vol. 40 No. 2, pp. 283-306.

Robinett, D., Benedetta, P.D. and Nguyet Anh, A. (2013), "Vietnam-report on the observance of standards and codes (ROSC): corporate governance country assessment", The World Bank, No. 88759, pp. 1-52.

Roodman, D. (2009), "How to do xtabond2: an introduction to difference and system GMM in Stata", Stata Journal, Vol. 9 No. 1, pp. 86-136.

Sá, T.M., Neves, E.D. and Góis, C.G. (2017), "The influence of corporate governance on changes in risk following the global financial crisis: evidence from the Portuguese stock market", Journal of Management and Governance, Vol. 21 No. 4, pp. 841-878. 
Salem, I.H., Ayadi, S.D. and Hussainey, K. (2019), "Corporate governance and risk disclosure quality: Tunisian evidence", Journal of Accounting in Emerging Economies, Vol. 9 No. 4, pp. 567-602.

Sewpersadh, N.S. (2019), "Governing board attributes as profitability influencers under endogeneity: an econometric analysis in South Africa", ACRN Joumal of Finance and Risk Perspectives, Vol. 8 No. 1, pp. 133-151.

Shakir, R. (2008), "Board size, executive directors and property firm performance in Malaysia", Pacific Rim Property Research Journal, Vol. 14 No. 1, pp. 66-80.

Shao, L. (2019), "Dynamic study of corporate governance structure and firm performance in China: evidence from 2001-2015", Chinese Management Studies, Vol. 13 No. 2, pp. 299-317.

Taghavi, M., Valahzaghard, M. and Amirjahadi, N. (2014), "An investigation on the effect of the corporation governance structure and free cash flow on over-investment", Management Science Letters, Vol. 4 No. 3, pp. 567-572.

Titman, S., Wei, K.J. and Xie, F. (2004), “Capital investments and stock returns”, Journal of Financial and Quantitative Analysis, Vol. 39 No. 4, pp. 677-700.

Vo, X.V. and Ellis, C. (2018), "International financial integration: stock return linkages and volatility transmission between Vietnam and advanced countries", Emerging Markets Review, Vol. 36, pp. 19-27.

Waheed, A. and Malik, Q.A. (2019), "Board characteristics, ownership concentration and firms' performance: a contingent theoretical based approach", South Asian Journal of Business Studies, Vol. 8 No. 2, pp. 146-165.

Wang, C.J. (2012), "Board size and firm risk-taking”, Review of Quantitative Finance and Accounting, Vol. 38 No. 4 , pp. 519-542.

Waweru, N. (2020), "Business ethics disclosure and corporate governance in Sub-Saharan Africa (SSA)", International Journal of Accounting and Information Management, Vol. 28 No. 2, pp. 363-387.

Wenwei, G.U.A.N. (2017), "Beijing consensus and development legitimacy: the evolution of China's foreign direct investment (FDI) regime from a law and development perspective", Asian Journal of Comparative Law, Vol. 12 No. 1, pp. 115-139.

Wintoki, M.B., Linck, J.S. and Netter, J.M. (2012), "Endogeneity and the dynamics of internal corporate governance", Journal of Financial Economics, Vol. 105 No. 3, pp. 581-606.

Wright, M., Siegel, D.S., Keasey, K. and Filatotchev, I. (Eds) (2013), The Oxford Handbook of Corporate Governance, Oxford University Press, Oxford, Vol. 28.

Yammeesri, J. and Kanthi Herath, S. (2010), "Board characteristics and corporate value: evidence from Thailand", Corporate Governance, Vol. 10 No. 3, pp. 279-292.

Yang, C.H., Ramstetter, E.D., Tsaur, J.R. and Ngoc Phan, M. (2015), "Openness, ownership, and regional economic growth in Vietnam”, Emerging Markets Finance and Trade, Vol. 51 No. sup1, pp. S224-S233.

\section{Further reading}

Maseda, A., Iturralde, T., Aparicio, G., Boulkeroua, L. and Cooper, S. (2019), "Family board ownership, generational involvement and performance in family SMEs: a test of the S-shaped hypothesis", European Journal of Management and Business Economics, Vol. 28 No. 3, pp. 285-300.

Sarhan, A.A. and Ntim, C.G. (2019), "Corporate boards, shareholding structures and voluntary disclosure in emerging MENA economies", Journal of Accounting in Emerging Economies, Vol. 9 No. 1, pp. 2-27.

\section{Corresponding author}

Tho Anh To can be contacted at: anhtho27@gmail.com

For instructions on how to order reprints of this article, please visit our website:

www.emeraldgrouppublishing.com/licensing/reprints.htm

Or contact us for further details: permissions@emeraldinsight.com

\section{Role of nonexecutive directors}

